\title{
The Segmentation of the Leech Nervous System Is Prefigured by Myogenic Cells at the Embryonic Midline Expressing a Muscle-specific Matrix Protein
}

\author{
Irmgard S. Thorey and Birgit Zipser \\ Department of Physiology, Michigan State University, East Lansing, Michigan 48824
}

In the leech, adult muscle cells and embryonic mesodermal/ myogenic cells express the cell-type-specific Laz 10-1 epitope on extracellular matrix-associated proteins. Using this muscle-specific epitope as a marker, we found the following correlations between the development of identifiable myogenic cells at the embryonic midline and the segmentation of the leech CNS into 32 reiterative ganglia.

(1) During the production of mesodermal and ectodermal stem cells, cell bodies of midline myogenic cells create 32 anterior-posterior intervals along the midline of the embryonic germinal plate. The mesoblasts then rearrange themselves into 32 somites whose spacing follows the intervals between the midline myogenic cell bodies.

(2) Bilateral segmental zones of myogenic differentiation originate in juxtaposition to the midline myogenic cells.

(3) The first two types of muscle precursors develop from midline and adjacent bilateral myogenic cells; they are the precursors of the CNS muscles and of three groups of ventral blood sinus muscles. These two types of muscle precursors demarcate the boundaries of the territory within which neuroblasts proliferate and coalesce into segmental hemiganglionic primordia: Cell bodies of muscle precursors, like cornerstones, demarcate the anterior and posterior borders of the hemiganglionic primordia; their longitudinal processes surround the expanding hemiganglionic primordia on the medial, lateral, dorsal, and ventral aspect.

The contours of muscle precursors and midline myogenic cells are sharply delineated by immunohistochemical staining of the Laz10-1 epitopes. In contrast, undifferentiated mesoblasts are surrounded by diffuse layers of stained epitopes, which are expressed at fluctuating levels. Because elevated levels of this matrix epitope are associated with mesodermal/myogenic cells undergoing morphogenetic rearrangements, it may participate in the molecular mechanisms underlying the segmentation of the nervous system.

In both invertebrate and vertebrate organisms, mesoderm-derived cells have been implicated in providing positional cues for the segmentation of the nervous system (Ho and Goodman, 1982; Ho et al., 1983; Keynes and Stern, 1987; Stern and Keynes, 1987). In vertebrates, mesodermal cells and differentiating mus-

\footnotetext{
Received May 25, 1990; revised Jan. 9, 1991; accepted Jan. 30, 1991.

This work was supported by a research grant from the Deutsche Forschungsgemeinschaft to I.S.T. and by NIH Grant NS 25117 to B.Z. We wish to thank Dr. W. Kopachik and R. N. Cole for critical reading of the manuscript.

Correspondence should be addressed to Birgit Zipser, Department of Physiology, 111 Giltner Hall, Michigan State University, East Lansing, MI 48824-1101.

Copyright (C 1991 Society for Neuroscience $0270-6474 / 91 / 111786 \cdot 14 \$ 03.00 / 0$
}

cles have been shown to express a variety of different surface or cxtraccllular matrix molecules that are implicated in facilitating morphogenetic cell rearrangements and axonal growth, among them fibronectin and laminin (Bronner-Fraser, 1985, 1986; England, 1986; Lash and Yamada, 1986; Jaffredo et al., 1988; Goodman et al., 1989; Hunter et al., 1989), cytotactin/ $\mathrm{J} 1 /$ tenascin (Chiquet and Fambrough, 1984; Chiquet-Ehrismann et al., 1986; Gatchalian et al., 1989), N-CAM (Rutishauser, 1984; Tosney et al., 1986), N-cadherin (Hatta and Takeichi, 1986), and a molecule bearing the L2/HNK-1 epitope (Thiery et al., 1985). However, these molecules are not mesoderm or muscle specific, because they are also expressed by neurons, glial, or epithelial cells.

In the leech, as in vertebrates, mesodermal cells are essential for the segmentation of the nervous system: Ablation of the $M$ teloblasts, which generate the mesoderm, prevented the proper segmentation of the CNS into 32 reiterative ganglia. In the absence of the mesoderm, neuroblasts, which are primarily derived from $\mathrm{N}$ teloblasts, did not organize themselves into bilaterally symmetrical hemiganglionic primordia (Blair, 1982; Zackson, 1984; Torrence et al., 1989). Neither the mesodermderived cell types that may provide the positional cues for the segmentation of the nervous system nor the molecular nature of these cues was identified.

Here, we report on the untogenesis of identifiable myogenic cells prior to the formation of the hemiganglionic primordia. As a marker we used a newly generated monoclonal antibody (mAb), Laz10-1, which recognizes an epitope located on a group of extracellular matrix-associated proteins that are expressed by adult muscle cells and embryonic mesodermal/myogenic cells. In the leech, the 32 reiterated or homologous segments develop with an anterior-posterior gradient of maturation. This gradient of maturation made it possible to trace the fate of individual cells by observing their homologues in morc anterior segments of the same leech. Our studies, carried out in the hirudinid leech Haemopis marmorata, revealed that the segmentation both of the mesoderm and of the CNS is prefigured by individual myogenic cells.

(1) We identified a novel cell type at the embryonic midline, the midline myogenic cell. Thirty-two midline myogenic cells are arranged along the germinal plate in regularly spaced anterior-posterior intervals, which determine the spacing of the 32 bilateral somites.

(2) The midline myogenic cells and the first myogenic cells differentiating bilaterally develop into the precursors of muscles that are associated with the CNS. These muscle precursors are established prior to gangliogenesis, and they surround the compartments within which neuroblasts proliferate and coalesce into hemiganglionic primordia. 


\section{Materials and Methods}

Production of antibodies. The monoclonal antibody Laz10-1, an IgG1, was obtained after immunization with deglycosylated $130-\mathrm{kDa}$ leech proteins. For immunization of six mice, proteins from 20 leech CNS (approximately $6 \mathrm{mg}$ protein) were separated by SDS-PAGE and transferred to zetabind membrane (Cuno, Inc., Meriden, CT). The 130-kDa region was excised from the membrane and incubated for $24 \mathrm{hr}$ at $37^{\circ} \mathrm{C}$ with $N$-Glycanase (Genzyme, Boston, MA) in buffer according to the manufacturer's instructions. The immunoblot strip was cut into pieces and minced with small scissors. Each mouse received $200 \mu \mathrm{l}$ of a suspension of the minced zetabind membrane in Freund's adjuvant, intraperitoneally, with an 18-Ga needle. For the final boost, the volume per mouse was doubled. Fusion was carried out with the myeloma line NS-1, using 75\% polyethylene glycol (PEG) buffered in HEPES and Dulbecco's modified Eagle's medium. Fused hybrids were selected by addition of hypoxanthine, aminopterin, thymidine (HAT) media supplement (Sigma, St. Louis, MO) to the culture medium. The hybridoma line, Laz10-1, was recloned three times by limited dilution.

Immunohistochemistry. For immunofluorescent stains of adult tissues, cryostat cross sections on slides were prepared from unfixed $\mathrm{Hae}$ mopois marmorata body segments. Slides were fixed in $4 \%$ paraformaldehyde for $30 \mathrm{~min}$, and unspecific binding sites were blocked for 15 min with $10 \%$ fetal calf serum and $0.2 \%$ Triton X-100. Hybridoma supernatant was applied overnight, followed by tetramethylrhodamine isothiocyanate (TRITC)-conjugated rabbit anti-mouse Ig antiserum (Dako Corp., Santa Barbara, CA; 1:50 in 10\% fetal calf serum) for $1 \mathrm{hr}$. For viewing, sections were mounted in $70 \%$ glycerol $/ 30 \%$ glycine buffer $(\mathrm{pH}, 9)$, to which $p$-phenylenediamine (Sigma) had been added to prevent bleaching of fluorescence.

For live stains of adult CNS, nerve cords were dissected, pinned out on Sylgard-coated dishes, decapsulated at the dorsal side, treated with $0.1 \%$ pronase (Protease type XIV; Sigma) for $30 \mathrm{~min}$, and allowed to heal for $2.5 \mathrm{hr}$ in leech culture medium (Zipser et al., 1989). The health of the muscle cells was verified by observing their ability to contract after a lateral pull on the connectives. The nerve cords were then incubated overnight in Laz10-1 hybridoma supernatant that had been concentrated by precipitation with $40 \%$ ammonium sulphate $(1: 1$ in leech culture medium), fixed, xylene extracted, and incubated with TRITC-conjugated rabbit anti-mouse IgG antiserum (Dako Corp.; 1:50 in $10 \%$ fetal calf serum $/ 2 \%$ Triton $\mathrm{X}-100$ ) for $2 \mathrm{hr}$. Control experiments were prepared in which the $\mathrm{mAb}$ was replaced by PBS. For viewing, nerve cords were dehydrated and mounted in fluoromount mountant (Gurr/Biomedical Specialties, Santa Monica, CA).

For embryonic whole-mount Laz10-1 stains, Haemopis leeches were bred as described previously (Cole et al., 1989). Embryos of various ages were released from their cocoon and opened at the side opposing the germinal plate. After extrusion of the yolk, the embryos were pinned out on Sylgard-coated dishes and fixed in $4 \%$ paraformaldehyde for 30 $\mathrm{min}$. Endogenous peroxidases were destroyed by immersion in methanol for $30 \mathrm{~min}$. Embryos were incubated with hybridoma supernatant and $0.5 \%$ Triton X-100 overnight, followed by HRP-conjugated rabbit antimouse IgG antiserum (Dako; 1:50 in 10\% fetal calf serum/0.5\% Triton $\mathrm{X}-100$ ) for $2 \mathrm{hr}$. For very young embryos, first and second antibody incubations were repeated ( $4 \mathrm{hr}$ and $2 \mathrm{hr}$, respectively). Color was developed with $0.03 \%$ diaminobenzidine.

For the embryo sections, whole embryos were fixed in $4 \%$ paraformaldehyde overnight for Laz10-1 stains, or in $3.7 \%$ formalin for 15 min, followed by extraction with cold acetone $\left(-20^{\circ} \mathrm{C}\right)$ for $15 \mathrm{~min}$ for staining with mAb Lan3-8. After removal of the yolk, embryos were stained as described above, embedded in glycol-methacrylate (Immunobed; Polysciences, Warrington, PA), and sectioned at $4 \mu \mathrm{m}$. HRPstained specimens were dehydrated and mounted in Permount (Fisher Scientific Co., Fair Lawn, NJ).

Microscopy. In order to view structures occurring within the embryonic whole-mounts at high magnification, a Nikon Labophot microscope fit with a Nikon Achr-Apl 1.4 oil-immersible condensor and bright-field optics was used, in combination with a $40 \times$ or $63 \times$ Zeiss Planapo oil-immersion lens. This allows the representation of stained structures within the focal range of the lens, while parts of the specimen lying outside the focal range remain optically invisible. Thus, stained cells occurring throughout the germinal plate can be viewed from the dorsal side without interference from underlying stained cells of the larval envelope. Use of these optics results in images with soft contours, especially when focusing deep within the tissue.
SDS-PAGE and immunoblots. Haemopis nerve cords, ventral blood sinuses, and peripheral muscle (penis sheath) were dissected out and minced with scissors in PBS containing protease inhibitors $(0.2 \mathrm{~mm}$ EGTA, $10 \mu \mathrm{g} / \mathrm{ml}$ pepstatin $\mathrm{A}, 10 \mu \mathrm{g} / \mathrm{ml}$ aprotinin, $10 \mu \mathrm{g} / \mathrm{ml}$ leupeptin, $20 \mu \mathrm{g} / \mathrm{ml}$ soybean trypsin inhibitor) before addition of SDS-PAGE sample buffer (Laemmli, 1970).

For the extraction experiments, $15 \mathrm{mg}$ of peripheral muscle tissue were minced with scissors in $300 \mu \mathrm{l}$ of distilled water containing inhibitors, spun down in a microfuge, and extracted $\left(1 \mathrm{hr}\right.$ at $\left.0^{\circ} \mathrm{C}\right)$ sequentially with $300 \mu \mathrm{l}$ each of the following solutions containing inhibitors: (1) distilled water, (2) $1 \mathrm{M} \mathrm{NaCl}$, and (3) $2 \%$ Triton X-100/1 mM CaCl 2 in $20 \mathrm{~mm}$ Tris/HCl (pH, 7.4); each was followed by centrifugation and one washing step. The supernatants were precipitated with ethanol $(75 \%$; $48 \mathrm{hr}$ at $-20^{\circ} \mathrm{C}$ ), and the precipitate was resuspended in SDS-PAGE sample buffer.

Proteins were separated electrophoretically and transferred to nitrocellulose (Towbin et al., 1979). The nitrocellulose membrane was fixed with $25 \%$ isopropanol and $10 \%$ acetic acid for $30 \mathrm{~min}$, and unspecific binding sites were blocked with $10 \%$ nonfat milk powder and $0.05 \%$ Tween 20 for $2 \mathrm{hr}$. Hybridoma supernatant was applied overnight, followed by ${ }^{125}$ I-conjugated goat anti-mouse IgG (New England Nuclear, Wilmington, DE; $150,000 \mathrm{cpm} / \mathrm{ml}$ in blocking solution) for $2 \mathrm{hr}$. Immunoreactive bands were visualized by autoradiography.

\section{Results}

Matrix-associated muscle proteins of hirudinid leeches contain the cell-type-specific Laz10-1 epitope

By immunizing mice with deglycosylated $130-\mathrm{kDa}$ CNS proteins of the hirudinid leech Haemopis marmorata, we have isolated an mAb, Laz10-1, that is specific for adult and embryonic muscle cells. In the adult leech, Laz10-1 stains both CNSassociated muscle cells and peripheral muscle cells, but no other cell types (Fig. 1). In the CNS, a pair of muscle cells, whose cell bodies are located at the dorsal neuropil border within each ganglion, projects numerous thin processes into the central axon tract, the connective (Coggeshall and Fawcett, 1964; Tulsi and Coggeshall, 1971). Laz10-1 stains these CNS muscle processes (Fig. 1A,B, small arrows). Staining with Laz10-1 has also revealed muscle processes in the ventral blood sinus that surrounds the CNS (Fig. 1A,B, large arrows). The muscle cells of the ventral blood sinus, described here for the first time in hirudinid leeches, form three bilateral muscle groups in the lateral, dorsal, and ventral wall of the blood sinus. We name them lateral, dorsal, and ventral blood sinus muscles. Two to three pairs of muscle fibers incorporated in the ventral blood sinus are also found in acanthobdellid and glossiphoniid leeches (Sawyer, 1986).

Peripherally, the antibody stains the large muscles of the body wall. As illustrated in Figure 1, $C$ and $D$, the muscle-specific antigen recognized by Laz10-1 is associated both with the surface (Fig. $1 C$, arrow) and with the interior (Fig. $1 D$, arrow) of these muscle cells. Both the large, spindle-shaped peripheral muscle cells and the thin processes of the CNS muscles share the same fine structure, which is diagrammatically represented in Figure $1 E$. It consists of a central sarcoplasm, which contains a nucleus, mitochondria, and the sarcoplasmic reticulum, and a corlex with spirally arranged myofibrils traversed by radial tubules of the sarcoplasmic reticulum (Pucci and Afzelius, 1967; Rosenbluth, 1972; Lanzavecchia, 1977). Intracellularly, the Laz10-1 antigen is localized to reticular structures within the central sarcoplasm.

Extracellular localization of the Laz10-1 epitope was verified by immunofluorescently staining live ganglia with Laz10-1. Figure $1 F$ shows a schematic representation of the pair of CNS muscle cells (densely stippled) at the dorsal border of the central 
A
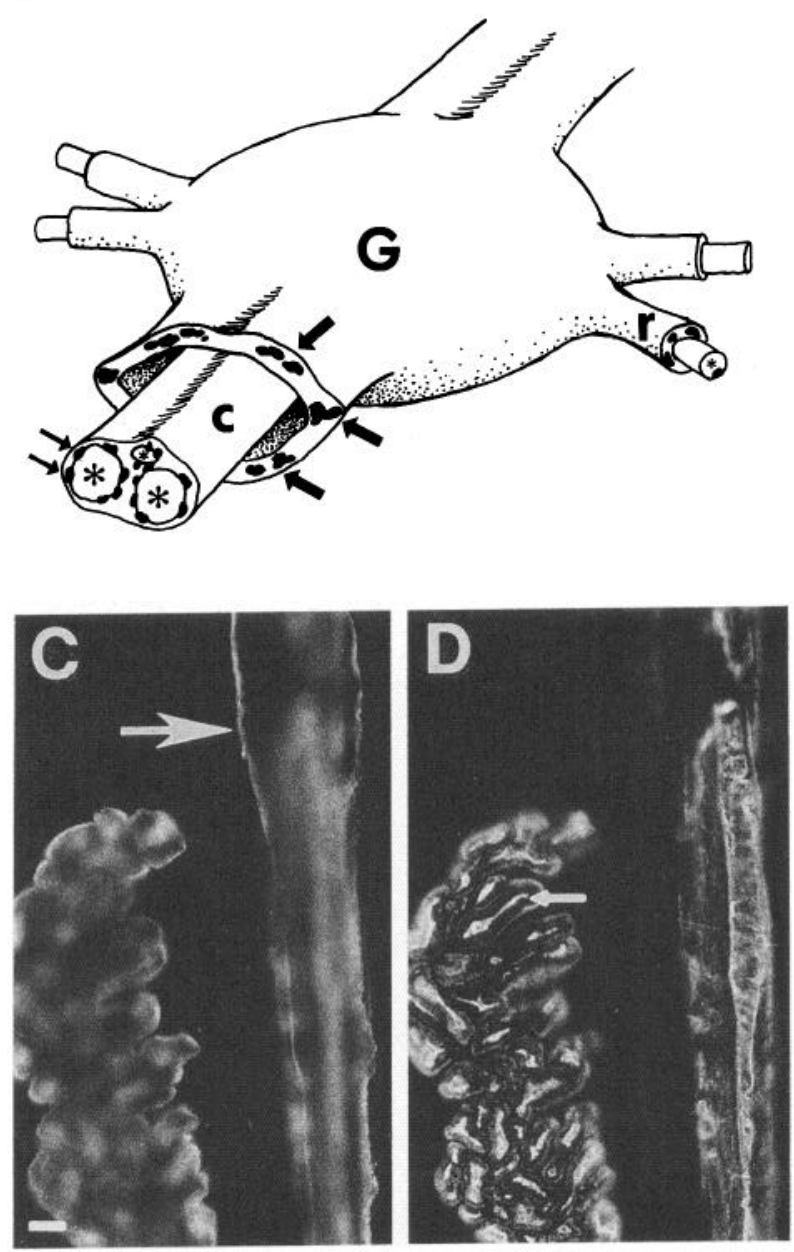
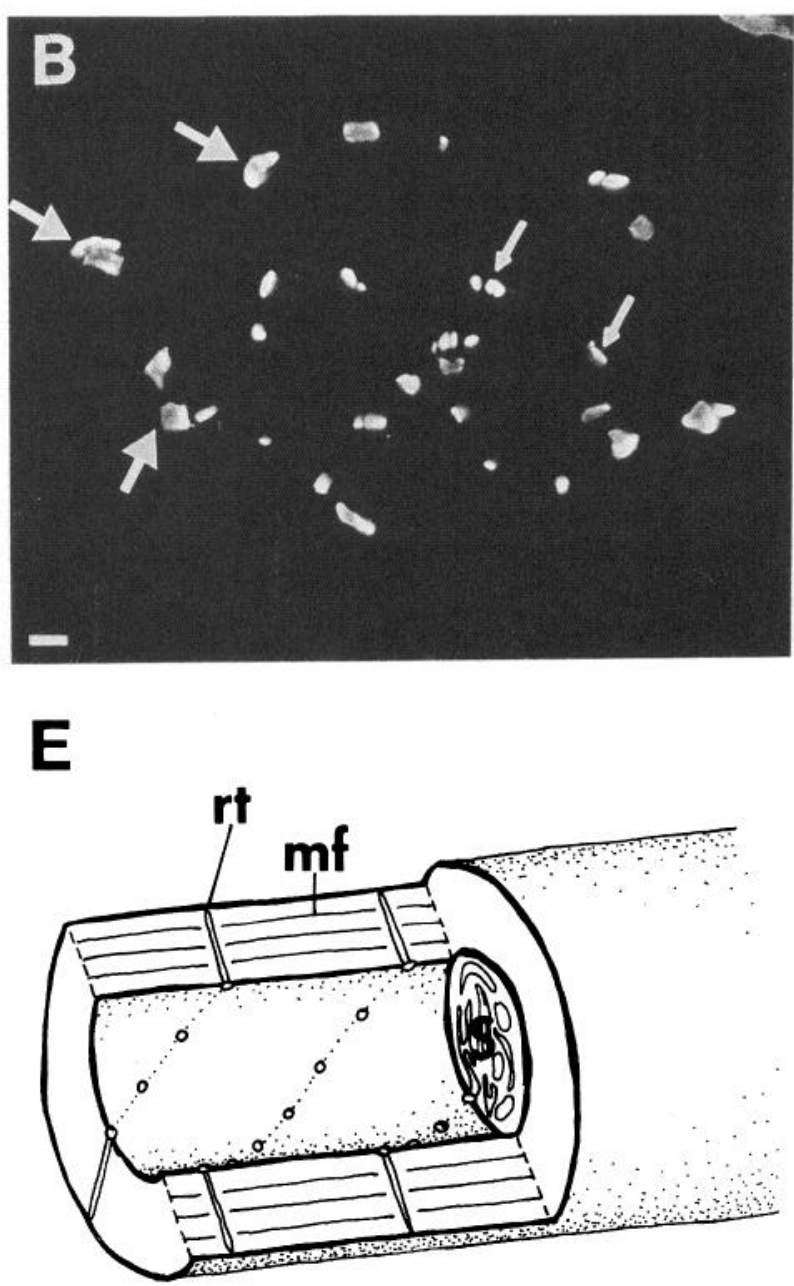
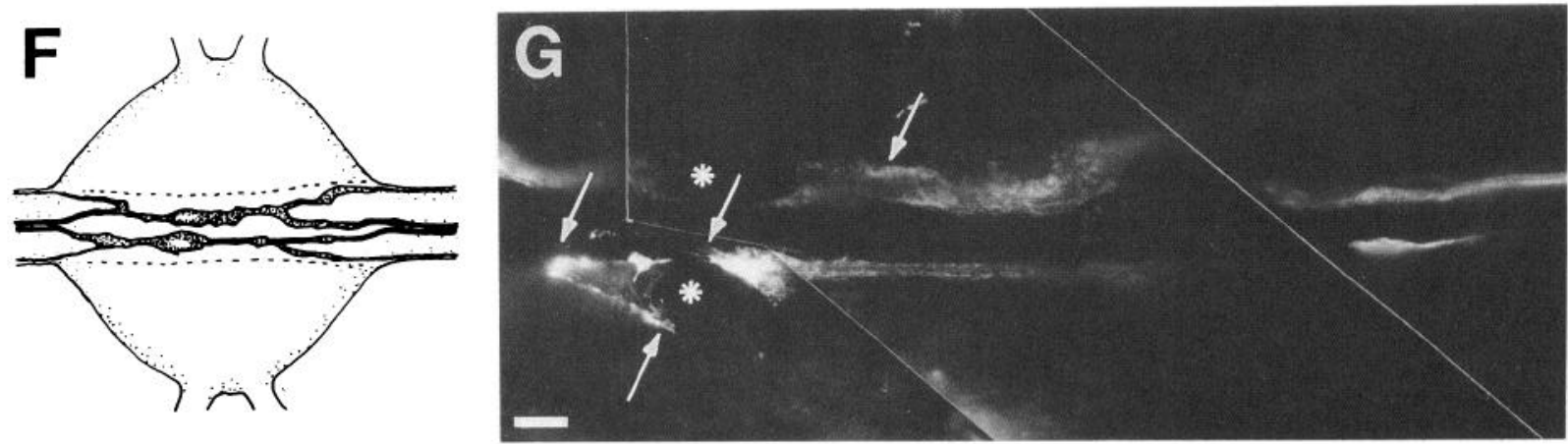

Figure 1. A muscle-specific antigen is expressed extracellularly by CNS muscles, blood sinus muscles, and peripheral muscles. A, A segmental leech ganglion $(G)$, with its connectives $(c)$ and roots $(r)$, is represented diagrammatically. Processes of the CNS muscles (small arrows) are embedded in the extracellular matrix tissue surrounding the axon tracts within the connectives (asterisks); processes of the blood sinus muscles (large arrows) are embedded in the wall of the ventral blood sinus surrounding the leech CNS. The peripheral nerve roots also contain muscle processes. $B$, Laz101-stained cross section ( $8 \mu \mathrm{m}$ thick) through the leech Haemopis marmorata illustrates the processes of CNS muscles (small arrows) and blood sinus muscles (large arrows), within and surrounding a connective. $C$ and $D$, Two focal planes of the same cross section illustrate two bundles of peripheral muscle cells sectioned at different angles. Laz10-1 stains their surface $(C$, arrow) and granular material within their sarcoplasmic core $(D$, arrow). $E$, A schematic drawing illustrates the fine structure of a leech muscle cell. The central sarcoplasm $(S)$, containing mitochondria and reticular membranes, is surrounded by a spiral array of contractile myofibrillar units $(m f)$ alternating with radial tubules $(r t)$. $F$, A schematic drawing of the dorsal aspect of a leech ganglion illustrates the positions of the paired cell bodies of CNS muscle cells and their processes (densely stippled) dorsal to the central neuropil region (area between broken lines). Anterior is to the left. $G$, A composite of three photomicrographs taken at different focal planes shows the neuropil region of a ganglion in which the pair of CNS muscle cells was stained live with Laz10-1. Indicated by asterisks are the nuclei of the two muscle cells, which are situated at the dorsal neuropil border. Fluorescent surface stain shows an uneven distribution along the muscle cell processes, with patches of stained fibrils that extend into the surrounding extracellular space (arrows). Scale bars, $10 \mu \mathrm{m}$. 


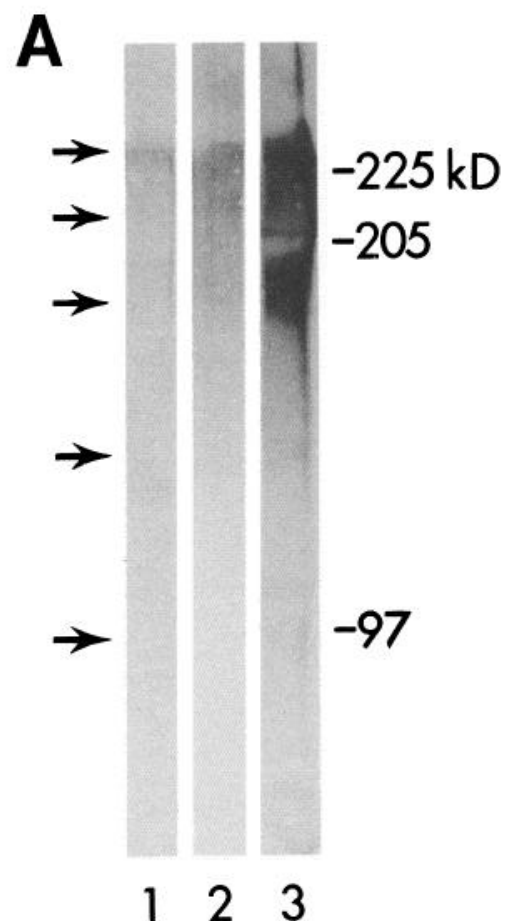

neuropil region (broken lines) of a ganglion. Figure $1 G$ shows the neuropil region of a ganglion stained live with Laz10-1 after opening the connective tissue capsule encasing the ganglion dorsally. At the dorsal neuropil border, the extracellular Laz10-1 stain is distributed unevenly along muscle cell bodies and their processes, and it is concentrated in patches of stained fibrils that extend from the surface of the muscle cells into the extracellular space (Fig. 1G, small arrows). No fluorescent stain was observed in control experiments performed in the absence of Laz10-1 antibody. These results indicate that a fraction of the Laz10-1 epitope is expressed extracellularly.

On immunoblots prepared from adult CNS, ventral blood sinus, and a peripheral muscle (penis sheath), Laz10-1 recognizes several broadly smeared protein bands (Fig. $2 A$ ). On blots prepared from the peripheral muscle (lane 3 ), major bands centered at 250,210 , and $180 \mathrm{kDa}$ and additional minor components at 130 and $95 \mathrm{kDa}$ are visible. On blots prepared from CNS and ventral blood sinus (lanes 1,2 ) in which muscle is a minor component, only the high-molecular-weight proteins are detected by Laz10-1. The broad smearing of the immunoblot bands suggest that Laz10-1 recognizes proteins of a high carbohydrate content. Experiments designed to analyze its carbohydrate domain have been inconclusive (data not shown). Because Laz10-1 recognizes its epitope after the antigen was treated with $\mathrm{N}$-Glycanase, which cleaves $\mathrm{N}$-linked carbohydrate chains, the epitope is presumably not located on an N-linked glycan. This is expected, because the antibody Laz10-1 was generated against proteins deglycosylated with $N$-Glycanase. The Laz10-1 antigen also does not bind to ConA, lentil lectin, or WGA, indicating that it does not contain core-fucosylated N-linked glycans of the high-mannose, complex biantennary, or hybrid types.

To determine other biochemical properties and the compartmentalization of the muscle-specific protein, CNS, blood sinus, and peripheral muscle tissues were subjected to sequential
Figure 2. The Laz10-1 epitope is expressed by a group of high-molecularweight, matrix-associated proteins. $A$, Immunoblots prepared from ventral blood sinus (lane 1; $10 \mathrm{mg}$ ), CNS (lane $2 ; 2$ nerve cords), and a peripheral muscle, the penis sheath (lane $3 ; 5 \mathrm{mg}$ ) were stained with Laz10-1. On the immunoblot prepared from the peripheral muscle, broadly smeared immunoreactive bands are centered at 250,210 and $180 \mathrm{kDa}$, and very weakly stained bands occur at 130 and $95 \mathrm{kDa}$ (arrows). On the blots prepared from CNS and ventral blood sinus, in which muscle is a minor component, only the higher-molecular-weight bands are visible. $B$, Solubility of Laz10-1 protein from $4.5 \mathrm{mg}$ peripheral muscle tissue, as determined by sequential extraction steps. Supernatants derived from the following steps were applied: homogenization in distilled water (lane 2) and extractions with distilled water (lane 3), with $1 \mathrm{M} \mathrm{NaCl}$ (lane 4), and with $2 \%$ Triton X-100 and $1 \mathrm{~mm} \mathrm{Ca}_{2} \mathrm{Cl}$ (lane 5). Lane 6 shows the insoluble fraction. Lane 1 shows total homogenate from $3 \mathrm{mg}$ muscle tissue for comparison. extractions, followed by immunoblot analysis. The extraction of Laz10-1 antigen from peripheral muscle is illustrated in Figure $2 B$; its extraction from CNS and blood sinus tissue was similar (not shown). Homogenization and extraction with distilled water determined that the Laz10-1 antigen did not appear in the soluble fraction (Fig. $2 B$, lanes 2,3). Subsequent extraction of the insoluble material with high salt yielded a minor fraction of noncovalently bound Laz10-1 antigen (lane 4); extraction with Triton X-100 did not solubilize additional antigen. The largest amount of Laz10-1 antigen appeared in the detergentinsoluble matrix (lane 6). Thus, the Laz10-1 epitope is expressed, in part extracellularly, on a group of matrix-associated, muscle-specific proteins.

\section{Myogenic cells in the germinal plate are identified by their Laz10-1 epitope}

Having established the Laz10-1 epitope as a specific marker for adult leech muscles, we analyzed its expression by developing muscle cells in 5-7-d-old embryos. The micrographs in Figures 3-7 illustrate that mAb Laz10-1 stains myogenic precursor cells through their development into embryonic muscles; the schematic representation in Figure 8 summarizes the development of the different Laz10-1-stained cells within the germinal plate of a 6-d-old embryo.

In all leeches, mesoderm and ectoderm are generated as rows of blast cells, called bandlets. Cell lineage studies showed that a pair of large cells, called $M$ teloblasts, generates a pair of mesodermal $\mathrm{m}$ bandlets, which stereotypically occupy a dorsal position in the nascent germinal plate. Four other pairs of teloblasts generate the ectodermal bandlets that become arranged in stereotypical medial-to-lateral sequence; $n, o, p$, and q (Weisblat et al., 1978, 1980, 1984; Weisblat and Stent, 1982). The hirudinid $\mathbf{M}$ teloblasts are the only teloblasts undergoing spiral divisions, which result in a characteristic zigzag arrangement of the dorsolateral mesodermal cells within the bandlets (Fer- 

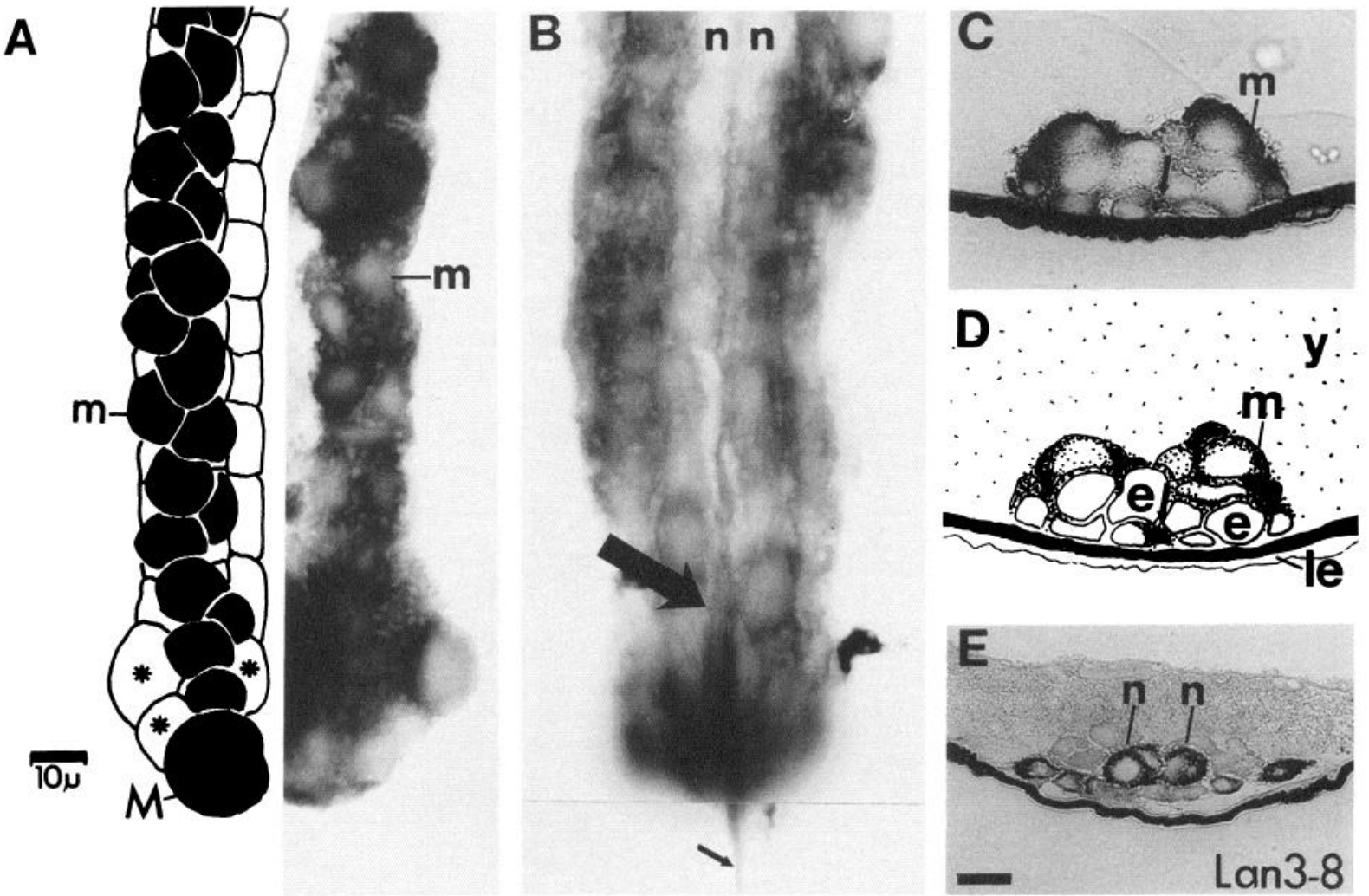

Figure 3. The Laz10-1 epitope is expressed by midline myogenic cells and mesoblasts during formation of the leech germinal plate in a 5-d-old embryo. In these and all subsequent whole-mount figures, anterior is $u p$. These and all subsequent cross-sectioned germinal plates will be oriented with the dorsal side up. A, Composite of a photomicrograph of a whole-mount stained with Laz10-1 and a schematic drawing illustrates the m bandlets $(\mathrm{m})$ at the dorsolateral aspect of the germinal plate. The $\mathrm{m}$ bandlets are formed by spiral divisions of the $\mathrm{M}$ teloblast $(M)$. The Laz10-1 stain is associated with mesoblasts arranged in zigzaglike pattern. The asterisks indicate three other teloblasts. $B$, At a ventral focal plane in the same embryo whole-mount, the process of a midline myogenic cell can be seen at the midline (large arrow). The ectodermal $\mathrm{n}$ bandlets ( $n$ ), ventromedial to the $\mathrm{m}$ bandlets, are unstained. The $\mathrm{o}, \mathrm{p}$, and $\mathrm{q}$ bandlets underlie the $\mathrm{m}$ bandlet and are not visible at this focal plane. The midline myogenic process continues past the teloblasts onto the posterior larval envelope at a slightly more ventral focal plane (small arrow). $C$, In a cross section of a sibling embryo, Laz10-1 stains a midline myogenic cell process (arrow) at the interface between the bilateral halves of the germinal plate and the larval envelope. Diffuse layers of stain are distributed along the margins of the dorsolateral mesodermal cells $(m)$ and within the extracellular spaces surrounding them. The muscles of the transient larval envelope at the ventral aspect of the germinal plate are also stained. $D$, A schematic drawing of the cross section shown in $C$ illustrates the diffusely stained mesodermal cells and a sharply delineated midline myogenic cell process. The unstained cells $(e)$, which are the ectodermal cells from the $\mathrm{n}, \mathrm{o}, \mathrm{p}$, and $\mathrm{q}$ lineage, form mediolateral rows at the ventromedial aspect of each embryonic half, separated by a midline myogenic process (arrow). The mesodermal cells $(m)$ overlie the ectoderm dorsolaterally. The bandlets are bordered ventrally by the larval envelope $(l e)$ and dorsally by the yolk $(y)$. E. A cross section of a sibling embryo stained with Lan3-8 illustrates stained neuroblasts within the ventromedial $\mathrm{n}$ bandlets $(n)$ adjacent to the midline and the laterally positioned epithelial precursors. The epithelial cells in the transient larval envelope are also stained. The epithelial and muscle cell layers of the larval envelope are closely apposed and cannot be distinguished from each other at this magnification. The unstained granular material on top of the germinal plate consists of yolk. To potentiate the Lan3-8 staining, embryos were only lightly fixed in formalin $(15 \mathrm{~min})$ and extracted with acetone; as a consequence, the germinal plate appears flatter than in Laz10-1-stained embryos fixed in paraformaldehyde overnight. Scale bars, $10 \mu \mathrm{m}$.

nandez and Stent, 1982). Because of their stereotypic position and division pattern, Laz10-1-stained cells at the dorsolateral aspect of the germinal plate were identified as mesoblasts.

In contrast to glossiphoniid leeches, where the two halves of the germinal plate first grow separately, then join (Weisblat et al., 1978, 1980; Zackson, 1982; Weisblat and Shankland, 1985), in hirudinid leeches the left and right bandlets are generated and remain in close apposition to each other. During embryonic days 5-7, the bandlets are growing posterior on the inner aspect of the larval envelope, the transient integument of the embryo that envelopes the yolk and contains embryonic muscles (Fernandez and Stent, 1982). After a series of cell divisions, the mesodermal cells within the $\mathrm{m}$ bandlets rearrange themselves into bilaterally symmetric segmental cell clusters called somites, in analogy to vertebrates (Blair, 1982; Zackson, 1982, 1984).The 32 reiterated or homologous segments develop with an anteriorposterior gradient of maturation. Thus, the fate of individual cells can be traced by observing their homologues in more anterior segments within the same embryo.

Most of the mesodermal cells in each segment will develop into a characteristic orthogonal grid of body wall muscles, as observed in older embryos (Kramer and Kuwada, 1983; Weisblat and Shankland, 1985; Torrence and Stuart, 1986; Jellies and Kristan, 1988b; Braun and Stent, 1989). The early expression of the Laz10-1 epitope makes it now possible to follow the development of identifiable midline and bilateral myogenic cells into different types of CNS muscles, blood sinus muscles, and the orthogonal grid of body wall muscles. 

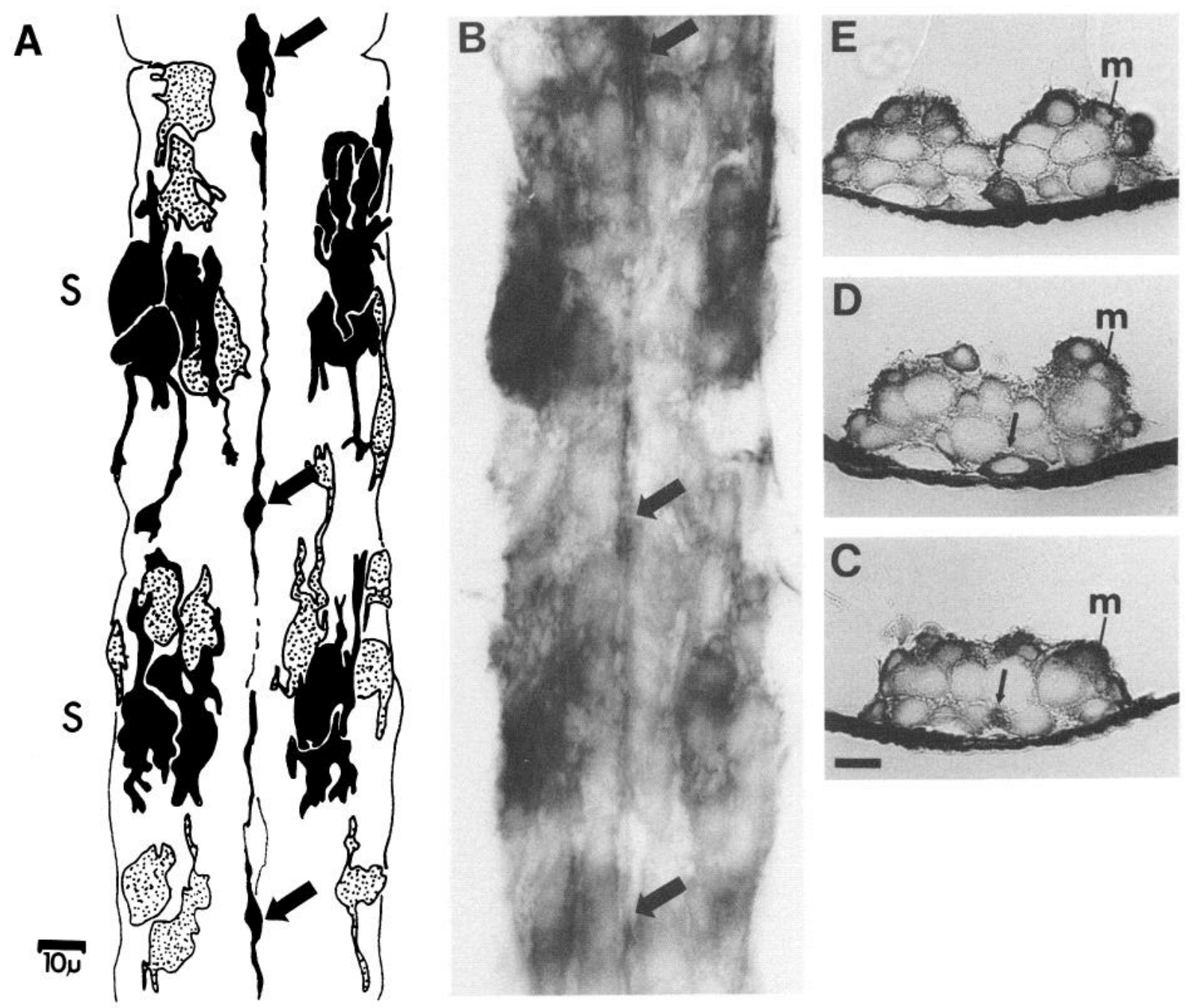

Figure 4. Bilateral mesodermal cells rearrange themselves into somites whose spacing follows the intervals between the midline myogenic cells. $A$ and $B$, Somite formation is shown in the anterior region of the same 5-d-old Haemopis embryo whole-mount as in Figure 3. The drawing (A) illustrates the positions of Laz10-1-stained ventromedial midline myogenic cells (arrows) and dorsolateral mesodermal cells (stippled and solid areas), as determined by focusing through the specimen. Note that the germinal plate is presented as viewed from the dorsal side; for example, some stained mesodermal cells are obscured by cells overlying them dorsally. The photomicrograph $(B)$ of the same region was taken at the focal plane of the midline myogenic cells (arrows). Some of the bilateral mesodermal cells, which were within the focal range of the optics, are also visible. Laz10-1 stains the dorsolateral mesodermal cells as they rearrange themselves into bilateral segmental somites $(S)$. Note the numerous filopodia and lamellipodia, indicating that the cells are engaged in morphogenetic movements. The somites form halfway between two neighboring midline myogenic cell bodies (arrows). $C-E$, The cross sections through a sibling embryo stained with Laz10-1 illustrate a posterior, less developed $(C)$, an intermediate $(D)$, and an anterior, more developed $(E)$ level of the germinal plate that is juxtaposed to corresponding regions in the wholemount. Stained midline myogenic cell bodies and processes (arrows) are located medially at the ventral aspect of the germinal plate. $C$, Two processes are closely apposed. $D$, The nucleus in the cell body is unstained. $E$, A cell body occurs apposed to a process. Thick layers of Laz10-1 stain extend along the margins of dorsolateral mesodermal cells $(\mathrm{m})$ and within the extracellular spaces surrounding them. Scale bars, $10 \mu \mathrm{m}$.

\section{Midline myogenic cells prefigure the segmentation of the germinal plate}

A 5-d-old germinal plate consists of a posterior region where teloblasts are still generating bandlets (Fig. 3) and an anterior region where segmentation of the bilateral mesoderm begins (Fig. 4). By staining with Laz10-1, we found that morphologically differentiated myogenic cells already occupy the embryonic midline, while the bandlets are still forming (Fig. 3B, large arrow). The cell bodies of these midline myogenic cells (Fig. $4 A, B$, arrows) are spaced at regular intervals (approximately $90 \mu \mathrm{m}$ ) and give rise to long stained processes projecting anteriorly and posteriorly towards their neighbors, thus forming a continuous chain of 32 cells extending from the larval mouth along the length of the germinal plate and a short distance out onto the posterior larval envelope (Fig. $3 B$, small arrow). Processes of neighboring midline myogenic cells overlap partially, because in cross section either one or two apposed thin, stained midline myogenic processes are visible ventrally, at the interface between left and right ectodermal bands and the larval envelope (Figs. $3 C, E ; 4 C$, arrow). Stained processes may extend as far as the next cell body (Fig. $4 E$, arrow). The cell bodies are stained, with an unstained nucleus (Fig. $4 D$, arrow).

In the nascent germinal plate, the Laz10-1 stain also accentuates the bilateral mesodermal cells. In an embryo whole-mount, mesodermal cells, identified by their typical zigzaglike pattern, 

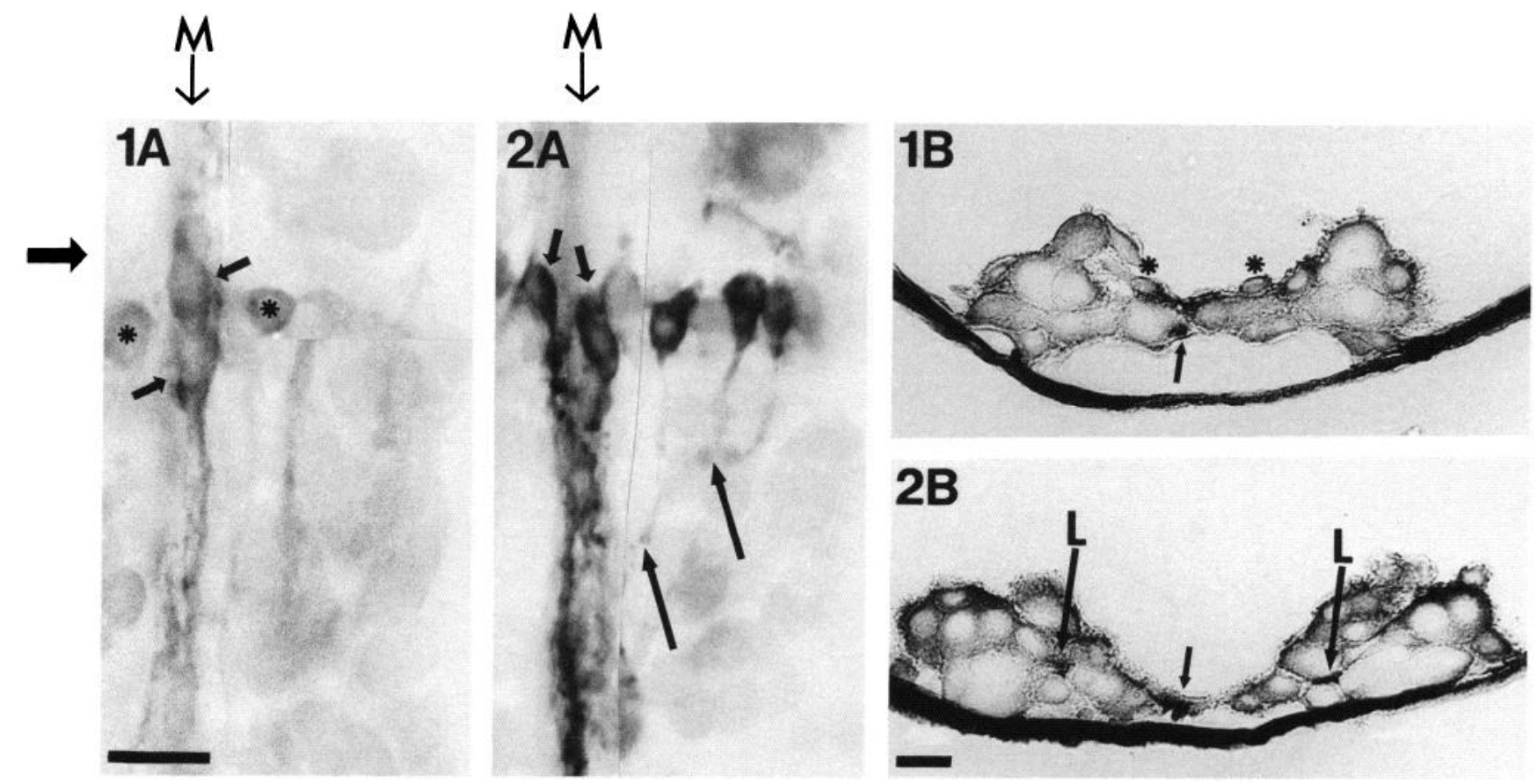

Figure 5. Bilateral zones of myogenic differentiation originate at the midline myogenic cell bodies in 6-7-d-old embryos. $1, A$ and $B$, illustrates a posterior, less developed segment; $2, A$ and $B$, shows an anterior, more developed segment. In the whole-mounts $(1 A, 2 A)$, the segmental boundary (large arrow to the left) and the position of the midline $(M)$ are indicated. Because the lateral germinal plate extends dorsolaterally from the midline myogenic cells, the figures are composites of photographs taken at different focal planes. Two sections through a Laz10-1-stained embryo ( $1 B, 2 B)$ were taken from segments equally developed as those illustrated in the whole-mounts $(1 A, 2 A$, respectively). Section planes are at the anterior segmental edges. 1A, Paired midline myogenic cell bodies (small arrows) project anteriorly and posteriorly directed processes. The first pair of stained bilateral myogenic cells (asterisks) has appeared amidst the weakly stained mesoderm, in close proximity to the midline myogenic cells. $I B$, A cross section illustrates that the cell bodies of the first bilateral myogenic cell pair (asterisks) are juxtaposed to the midline myogenic processes (arrow) at the dorsal aspect of the germinal plate. As seen here, the germinal plate is easily separated from the larval envelope during fixation. $2 A$, In a medial-to-lateral sequence, additional bilateral myogenic cell pairs differentiate in myogenic differentiation zones, which originate at the midline myogenic cell bodies (small arrows) and extend transversally along the anterior aspect of the segmental mesodermal tissue block. These bilateral myogenic cell pairs project posterior processes that frequently join each other or the midline for a short distance (large arrows). $2 B$, In a cross section, the processes of bilateral myogenic cells are represented by stain extending in patches and sheets along the dorsal edge of the germinal plate. The first precursors of the blood sinus muscles $(L)$ have appeared halfway between the midline myogenic processes (small arrow) and the lateral edge of the germinal plate. Scale bars, $10 \mu \mathrm{m}$.

exhibit diffuse staining with Laz10-1 (Fig. $3 A, \mathrm{~m}$ ). As seen in embryonic cross sections (Figs. $3 C, 4 C-E$ ), the Laz10-1 stain extends in broadly smeared layers along the margins of dorsolateral mesodermal cells. The level of this diffuse stain decreases sharply toward more ventrally and medially located cells. Ventromedial cells, which include the $\mathrm{n}$ bandlet cells from which most of the neuroblasts (n) originate (Kramer and Weisblat, 1985; Bissen and Weisblat, 1987; Stuart et al., 1989), are unstained. In contrast to the diffuse staining of dorsolateral mesoblasts, the contours of the cross-sectioned midline myogenic cells (and of the individual myogenic cells differentiating later) are sharply delineated by the Laz10-1 stain (Figs. $3 C, 4 C-E$, 57). The muscle cells of the transient level envelope (le) are also stained by Laz10-1.

In order to correlate the location of myogenic cells and neuroblasts, neuroblasts were stained with the mAb Lan3-8. mAb Lan3-8 recognizes an internal protein of neuronal and epithelial cells, probably their common intermediate filament protein (Hogg et al., 1983; McKay et al., 1984). Here, we show that Lan3-8 also recognizes these antigens during early embryogenesis. Because the two antibodies, Laz10-1 and Lan3-8, require different fixations for optimally staining myogenic cells and neuroblasts, respectively, pairs of homologous cross sections from sibling embryos stained with either Laz10-1 or Lan3-8 were analyzed, rather than one double-labeled cross section. Lan3-8 stains two distinct groups of cells in the germinal plate (Fig. $3 E$ ). The medial group is the neuroblasts of the $n$ bandlet (Fig. $3 E, \mathrm{n})$, the lateral group is epithelial cell precursors and, presumably, a few neuroblasts differentiating from o, p, q, and $\mathrm{m}$ bandlets. The two cross sections (Fig. $3 C, E$ ) confirm, first, that the Laz10-1 epitope is associated with dorsolateral mesodermal cells and not with neuroblasts, and second, that at this stage neuroblasts are located within the ventromedial $\mathrm{n}$ bandlets in close proximity to the midline myogenic cells. The epithelial cells of the transient larval envelope are also stained with Lan38. The thin epithelial and muscle layers of the larval envelope are contiguous and cannot be differentiated from each other in micrographs of cross sections.

Following a period of mesoblast proliferation, segmentation begins within the bilateral mesoderm (Fig. 4). Regions of proliferating mesoblasts are only weakly stained by Laz10-1; in contrast, mesodermal cells that rearrange themselves into somites (Fig. $4 A, \mathrm{~S}$ ) are accentuated by stronger stain. In a wholemount, segmentally arranged Laz10-1-stained dorsolateral cells project numerous anterior-posterior filopodia and lamellipodia typical of migrating cells (Fig. $4 A, B$ ). The left and right somites 

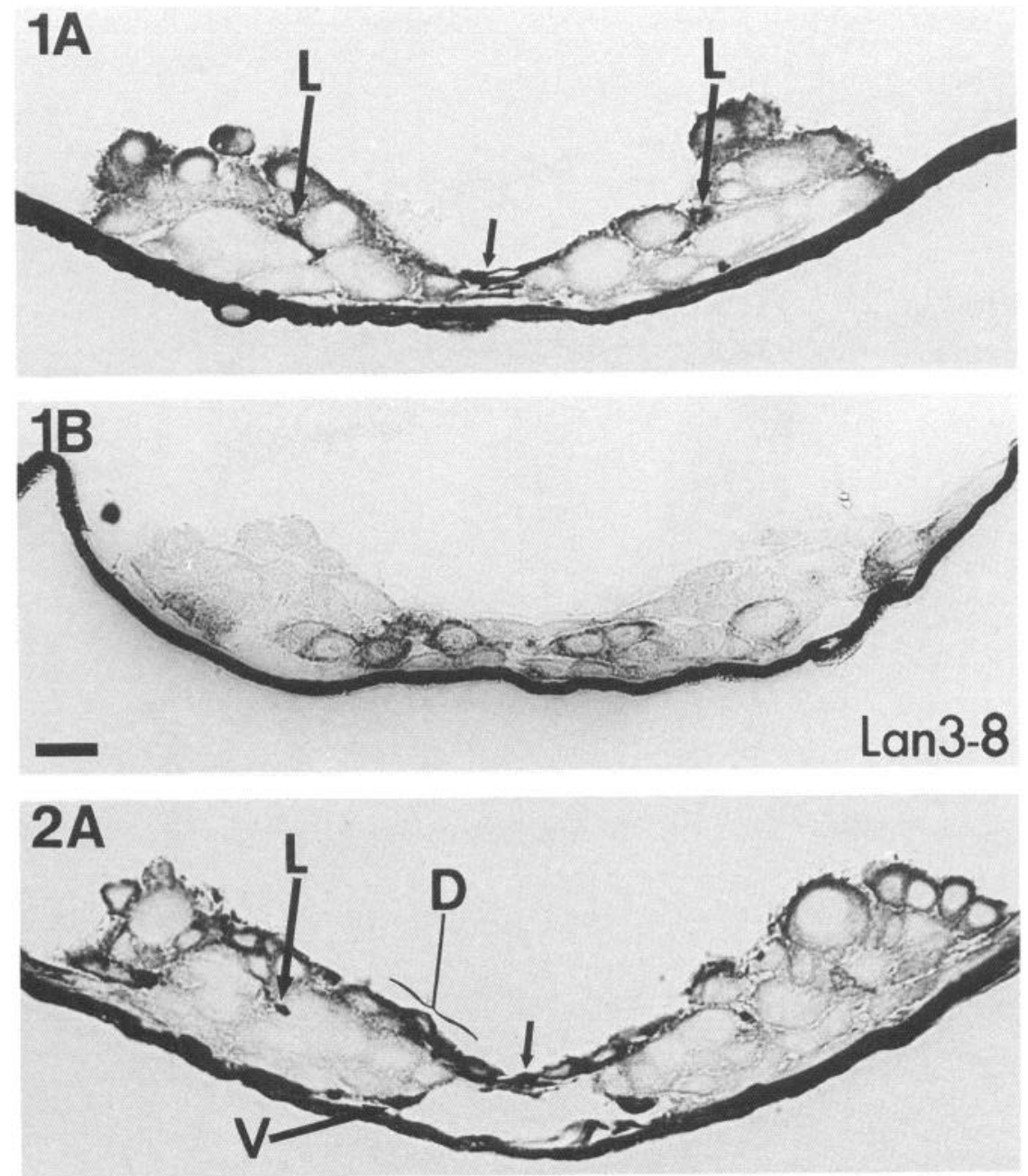

2B

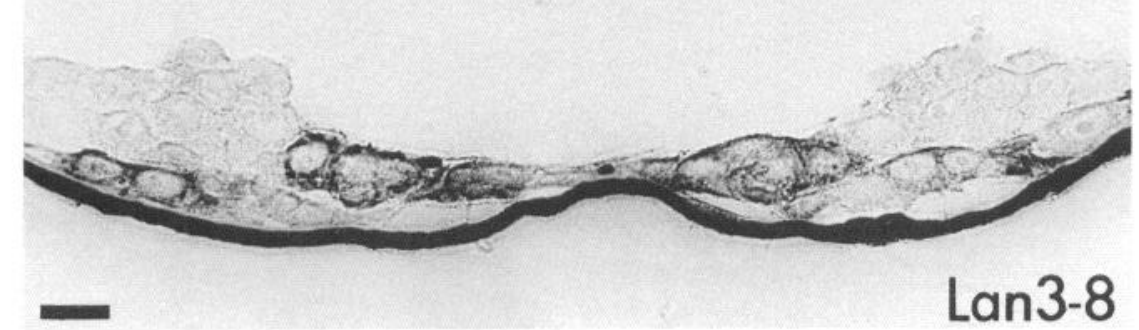

Figure 6. Neuroblasts proliferate within the boundaries demarcated by the precursors of CNS muscles and blood sinus muscles. The relative positions of muscle precursors stained with Laz10-1 and of proliferating neuroblasts stained with Lan3-8 are compared in sections of equally developed segments taken from 6-7-d-old sibling embryos. A posterior, less developed segment $(1, A$ and $B)$ and a more anterior, more developed segment $(2, A$ and $B$ ) are illustrated. $1 A$, Processes of the CNS muscle precursors (small arrow) divide the germinal plate into left and right hemispheres, with a cell-free space at the midline. The processes of the lateral group of blood sinus muscle precursors stained with Laz10-1 are visible as fascicles $(L)$, separating a medial cluster of two or three unstained cells from the lateral part of each embryonic hemisphere. $1 \mathrm{~B}$, Bilateral loose clusters of two or three neuroblasts strongly stained by Lan 3-8 occur immediately adjacent to the midline. The laterally positioned Lan3-8 stained cells are mostly epithelial cell precursors. $2 A$, The cell bodies of the dorsal blood sinus muscle precursors $(D)$ have appeared dorsally, close to the CNS muscle processes (small arrow). Processes of the ventral blood sinus muscle precursors $(V)$ have also assumed their stereotypic position. The four groups of muscle precursors now surround a medial cluster of three to five unstained cells in each embryonic hemisphere. The cellfree space at the midline has widened. $2 B$, Lan3-8 stains a medial cluster of three to five cells in each embryonic hemisphere. The Lan3-8 stained epithelial precursors are placed laterally. Scale bars, $10 \mu \mathrm{m}$. develop simultaneously at an anterior-posterior position halfway between two successive midline myogenic cell bodies (Fig. $4 A, B$, arrows). The borders between two neighboring somites, which are demarcated by the midline myogenic cell bodies, will develop into the boundaries between the embryonic segments.

\section{Bilateral myogenic cells differentiate stereotypically in a medial-to-lateral sequence initiating from the midline myogenic cells}

In 6-7-d-old embryos (Figs. 5-7), the germinal plate has widened, and segmental boundaries have developed (Fig. 5.1 $\mathrm{A}$, large arrow; $2 A$ ). At the position of the previously single midline cell body, a pair of closely apposed stained cell bodies $(3-4 \mu \mathrm{m}$ in diameter) now demarcates each anterior segmental edge and projects multiple stained processes along the embryonic midline (Figs. 5, 6, small arrows), thus dividing the germinal plate into two separate hemispheres. At this stage, undifferentiated mesoderm is only weakly stained with Laz10-1.

From bilateral mesodermal cells, the first myogenic cells are now differentiating. Differentiating bilateral myogenic cells are detected by their increasingly strong staining with Laz10-1. First, one stained bilateral myogenic cell pair (Fig. 5.1A,B, asterisks) appears in close proximity to the midline myogenic cell bodies. More bilateral myogenic cell pairs then differentiate in a medialto-lateral sequence. Thus, a zone of myogenic differentiation originates next to the midline myogenic cells. It extends trans- 
Figure 7. Hemiganglionic primordia coalesce within the boundaries demarcated by the precursors of CNS muscles and blood sinus muscles. In anterior segments of a 6-7-d-old embryo, primordia of segmental hemiganglia have coalesced and are microscopically visible as compact cell clusters in a wholemount stained with $\operatorname{Laz10-1}(A, B)$. Cross sections of sibling embryos stained with Laz10-1 $(C)$ and Lan3-8 $(D)$ were taken from equally developed segments. $A$ and $B$, The same three segments of an embryo whole-mount were photographed at two focal planes. Segmental borders are indicated by large arrows at the margins. The cell bodies of CNS muscle precursors $(B$, small arrows) demarcate the anterior-medial borders of unstained hemiganglionic primordia $(N)$. The processes of the CNS muscle precursors project longitudinally into a cell-free corridor at the embryonic midline. The cell bodies of the lateral blood sinus muscle precursors ( $B$, large arrows) demarcate both the anterior-lateral and the posterior-lateral borders of the hemiganglionic primordia. Their processes separate the hemiganglionic primordia from lateral, peripheral tissue. In a dorsal focal plane $(A)$, cell bodies of dorsal blood sinus muscle precursors (arrows) demarcate the dorsomedial boundaries of the hemiganglionic primordia. Stained primordia of peripheral muscles are visible in the lateral parts of the germinal plate. $C$, In a cross section stained with Laz10-1, processes of the CNS muscle precursors (small arrows) separate bilateral unstained compact hemiganglionic primordia that contain about 10 cells each $(N)$. Dorsal processes of blood sinus muscle precursors at left and at right of the midline $(D)$ delineate the dorsal edges, while lateral processes $(L)$ delineate the lateral edges and ventral processes $(V)$ mark the ventral edges of each hemiganglionic primordium $(N)$. Stained peripheral muscle precursors are visible in the lateral parts of the germinal plate. $D$, In a cross section stained with Lan3-8, about 10 stained neuroblasts are visible within each of bilateral hemiganglionic primordia $(N)$, with well-defined boundaries. Scale bars, 10 $\mu \mathrm{m}$.
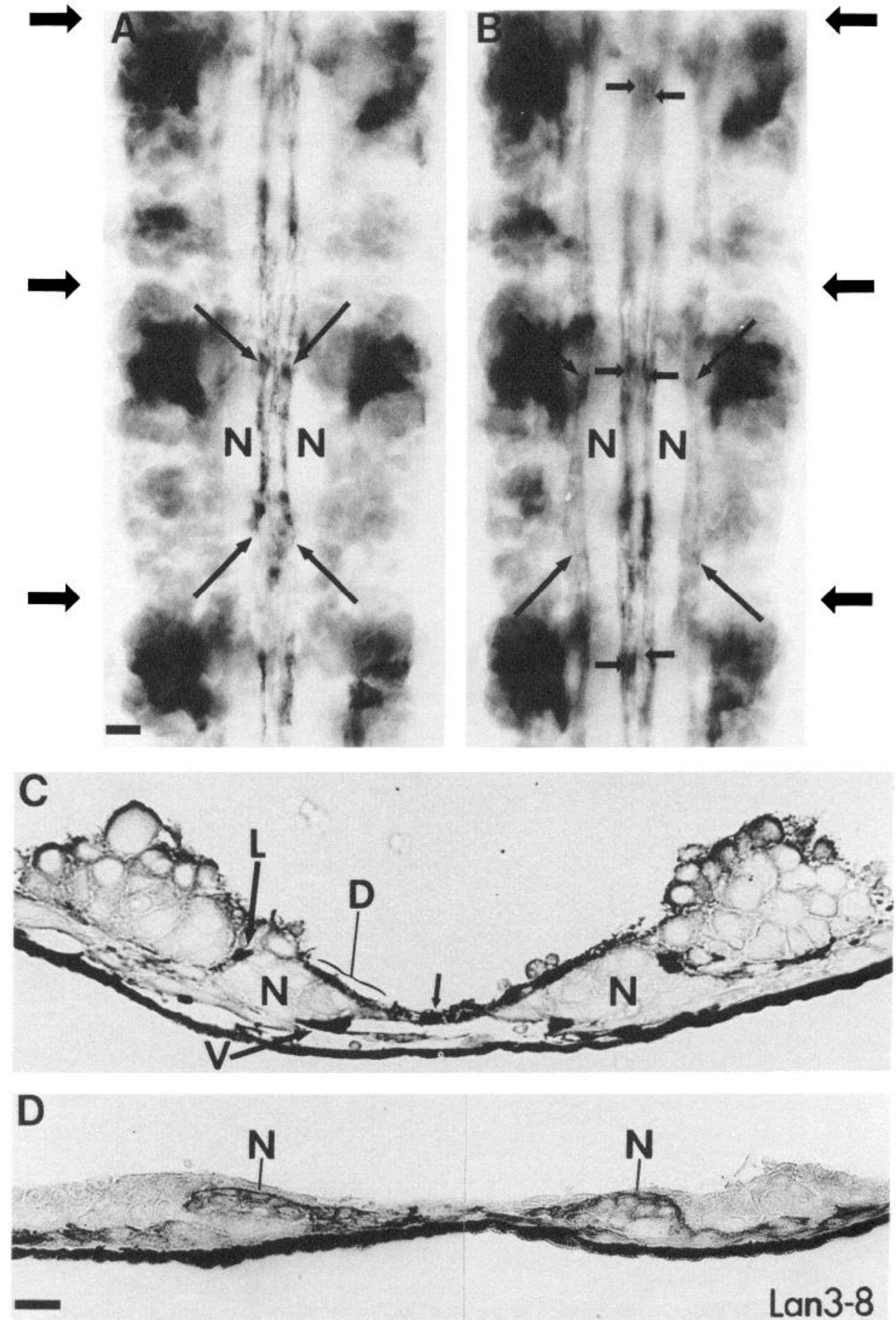

versally along the anterior aspect of the somite toward the lateral edges of the germinal plate (Fig. 5.2A). The bilateral myogenic cell pairs project thin, elongated processes, first posteriorly, then anteriorly, at right angles to the transversal myogenic differentiation zones. As these processes grow, they are frequently seen to join each other or the midline myogenic processes for a short distance (Fig. 5.2A, large arrows). In cross section (Figs. $5.2 B, 6.1 A, 2 A$ ), processes of bilateral myogenic cells stained by Laz10-1 extend along the dorsal aspect of the germinal plate. The bilateral myogenic differentiation zones provide the precursors for the blood sinus muscles and peripheral longitudinal muscles. Each segmental myogenic differentiation zone provides myogenic cells whose processes eventually extend posteriorly within the same segment and also anteriorly into the next segment.

\section{Proliferating neuroblasts are surrounded by the processes of CNS muscle and blood sinus muscle precursors}

Five levels of myogenic differentiation are shown in Figures 57 , spaced two or three segments apart in posterior-to-anterior progression. The more posterior segments illustrate the beginning of myogenic differentiation; the more anterior segments 


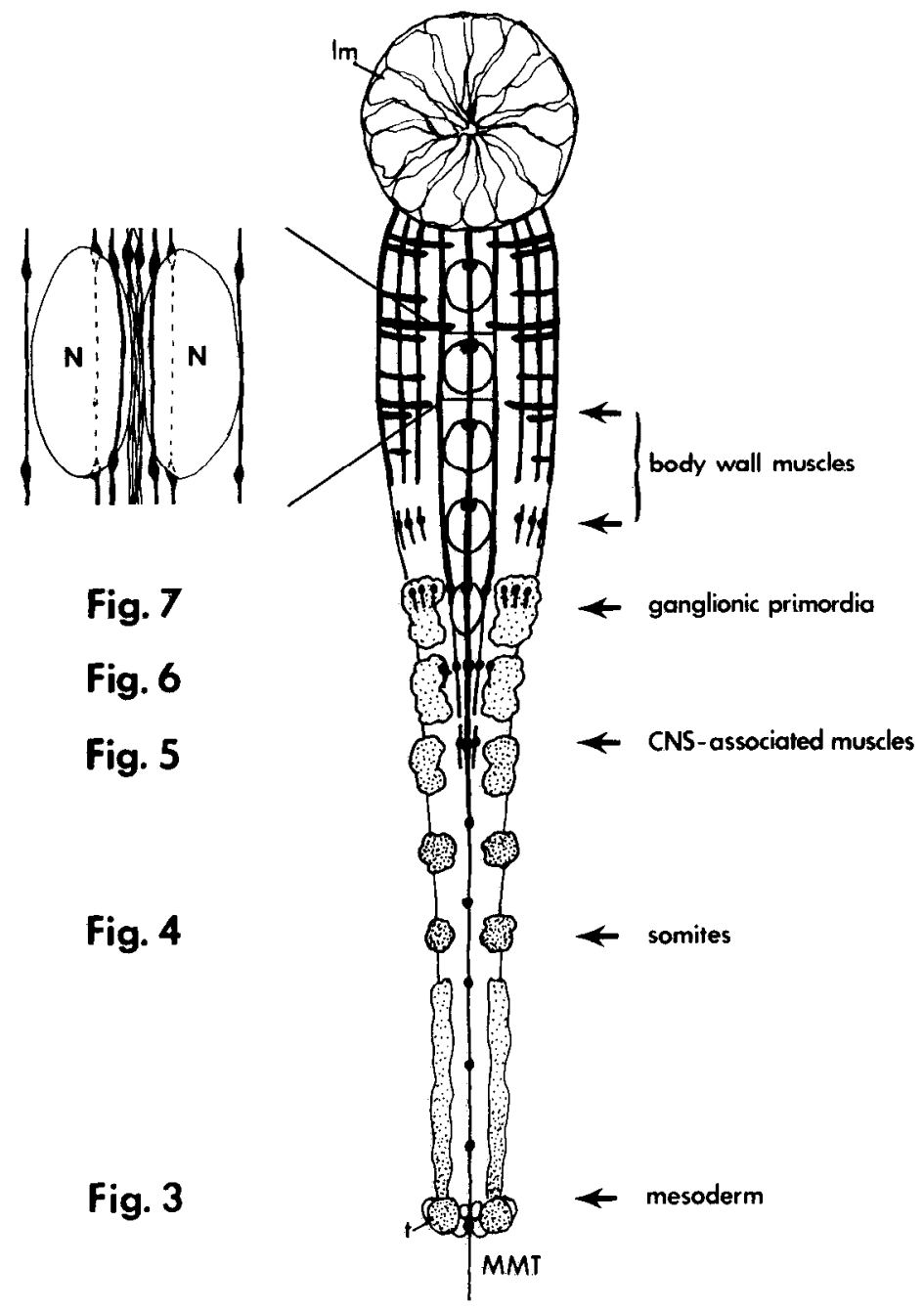

Figure 8. Development of leech muscle precursors is stereotypic from segment to segment. In summary, the different steps in the development of muscles are represented in a drawing of the germinal plate of a Haemopis embryo maintained at $20^{\circ} \mathrm{C}$ for $6 \mathrm{~d}$. The embryo is viewed from the side opposite the larval envelope, and anterior is up. Approximate positions of Figures 3-7 are indicated on the left of the drawing. The drawing reproduces the anterior-posterior developmental gradient observed within one embryo faithfully, but shows fewer segments than are present in an actual embryo. Due to the developmental gradient, the formation of the structures listed to the right of the diagram can be visualized in one embryo. A tract of midline myogenic cells $(M M T)$ is already found at the ventral midline, while five pairs of teloblasts $(t)$ are still forming mesoderm and ectoderm at the posterior end of the germinal plate. From the larval mouth $(\mathrm{lm})$, the midline myogenic cells occur in regularly spaced intervals along the length of the germinal plate and onto the posterior larval envelope. Bilateral mesodermal cells within the mesodermal bandlet (stippling) soon rearrange themselves into segmental somites whose spacing follows the intervals between the midline myogenic cells. Originating from the midline myogenic cells, precursors of CNS muscles and blood sinus muscles differentiate and demarcate boundaries for proliferating neuroblasts (inset): Their processes surround paired clusters of neuroblasts, which coalesce into segmental hemiganglionic primordia left and right of the midline $(N)$; their cell bodies indicate the anterior and posterior boundaries of the coalescing ganglionic primordia. Anteriorly, the germinal plate widens, and longitudinal and circular muscle precursors appear, completing the formation of the orthogonal muscle grid characteristic of older leech embryos. The level of muscle-specific antigen expressed by mesodermal/myogenic cells fluctuates (indicated by the density of stippling); it is high (1) in mesoblasts forming mesodermal bandlets, (2) in mesodermal cells rearranging themselves into somites, and (3) in differentiating myogenic cells, muscle precursors, and adult muscle cells.

illustrate the stereotypic positions that the CNS muscle and blood sinus muscle precursors assume. In Figures 6 and 7, cross sections of equally developed segments from sibling embryos stained with Laz10-1 and Lan3-8 are compared to determine the relative locations of muscle precursors and proliferating neuroblasts.

The midline myogenic cells (Figs. 5-7, small arrows) can now be identified by their position as the precursors of the CNS muscles. Their processes extend along a cell-free corridor at the embryonic midline that will later contain the connectives and the ganglionic neuropil regions.
The first muscle precursors to develop from bilateral myogenic cells can be identified by their positions as the blood sinus muscle precursors. First, a lateral blood sinus muscle precursor (L) establishes itself. In Figure 5.2B, it has separated itself from the dorsal myogenic differentiation zone and assumed its stereotypic position halfway between the midline and the lateral edge of the germinal plate. More anteriorly (Fig. 6.1A), the CNS muscle precursors (small arrow) and the lateral blood sinus muscle precursors now surround a cluster of two to three unstained cells in each embryonic hemisphere. The Lan3-8-stained sibling cross section illustrates two or three stained neuroblasts bilateral 
to the midline (Fig. 6.1B); other Lan3-8-stained cells that could be epithelial cell precursors or precursors of peripheral neurons are located at the lateral aspects of the germinal plate. Still more anteriorly (Fig. 6.2A), the dorsal (D) and ventral (V) groups of blood sinus muscle precursors have assumed their stereotypic positions at the dorsal and ventral aspect of the embryonic midline region, respectively. The CNS muscle and lateral blood sinus muscle precursors continue to occupy medial and lateral positions. The three blood sinus muscle precursors and the CNS muscle precursors now surround a cluster of three to five unstained cells in each embryonic hemisphere. The Lan3-8-stained sibling cross section illustrates that the number of stained neuroblasts has increased to three to five cells bilateral to the midline.

At first, all three blood sinus muscle precursors consist of single processes with cell bodies at the anterior segmental edges. Subsequently, they develop into bundles containing several processes, with cell bodies occurring at the anterior segmental edge and at a posterior position in the segment.

\section{The cell bodies of CNS muscle and blood sinus muscle precursors demarcate the anterior and posterior borders of the coalescing segmental hemiganglionic primordia}

After the CNS and blood sinus muscle precursors have assumed their stereotypic positions, the bilateral clusters of neuroblasts coalesce into microscopically visible hemiganglionic primordia (Fernandez and Stent, 1982). Hemiganglionic primordia can be observed as compact, unstained cell clusters (Fig. $7 A, B, \mathrm{~N}$ ) in whole-mounts stained with Lazl0-1. At this developmental stage, the segments have expanded in anterior and posterior directions. The cell bodies of the CNS muscle precursors (Fig. $7 B$, small arrows) are no longer located at the anterior segmental edges (large arrows at right). They now demarcate the anterior-medial borders of the hemiganglionic primordia $(\mathrm{N})$.

The cell bodies of the blood sinus muscle precursors also are closely associated with the borders of the segmental hemiganglionic primordia: At the dorsal aspect of each hemiganglionic primordium, the cell bodies of the dorsal blood sinus muscle precursors (Fig. 7A, large arrows) demarcate both its anteriormedial and its posterior-medial borders. The cell bodies of the lateral blood sinus muscle precursors demarcate the anteriorlateral and posterior-lateral borders of each hemiganglionic primordium (Fig. $7 B$, large arrows). At the ventral aspects of each hemiganglionic primordium, the cell bodies of the ventral blood sinus muscle precursors demarcate its anterior and posterior borders (not shown).

A cross section through a Laz10-1-stained cmbryo at this developmental stage (Fig. 7C) illustrates that blood sinus muscle precursors have developed into bundles consisting of multiple processes $(\mathrm{L}, \mathrm{D}, \mathrm{V})$. They now surround an unstained compact cluster $(\mathrm{N})$, which has increased to about 10 cells, in each embryonic hemisphere. The number of stained neuroblasts visible within the bilateral hemiganglionic primordia (N) of a Lan3-8stained sibling cross section (Fig. $7 D$ ) has also increased to about 10 cells.

\section{Discussion}

We have followed the ontogenesis of identifiable myogenic cells at the embryonic midline, using a newly generated monoclonal antibody, Laz 10-1, to an epitope that is muscle-specific in adult leeches. As determined by immunohistochemical stains of adult leeches, the epitope is specifically associated with muscle cells, and it is expressed extracellularly in patches of fibrils that might be sites where the muscle cells are anchored within the extracellular matrix of the basal lamina. It also occurs in reticular structures within the sarcoplasmic core, while it is absent from the contractile cortex. Presumably, the intracellular epitopes are located on newly synthesized antigen molecules within the sarcoplasmic reticulum, Golgi apparatus, and secretory granules.

mAb Laz 10-1 was generated by injecting mice with $130-\mathrm{kDa}$ leech CNS protein deglycosylated with N-Glycanase. Previous immunization with $130-\mathrm{kDa}$ protein had produced $\mathrm{mAbs}$ against 130-kDa glycoproteins specific to sensory afferents, glial cells, and connective tissue (Flaster et al., 1983; Flaster and Zipser, 1987; Peinado et al., 1987; Bajt et al., 1990). Immunization with deglycosylated $130-\mathrm{kDa}$ protein resulted in 10 out of 33 mAbs recognizing Laz 10-1-like epitopes. On immunoblots prepared with muscle protein, mAb Laz10-1 only stains a minor hand at $130 \mathrm{kDa}$; the major bands recognized by Laz10-1 are centered at 250,210 , and $180 \mathrm{kDa}$. Thus, even though $130-$ $\mathrm{kDa}$ leech proteins only have a low abundance of the Laz10-1 epitope, the majority of the mAbs generated against the deglycosylated $130-\mathrm{kDa}$ gel band are directed against this epitope. Therefore, the Laz 10-1 epitope appears to be highly immunogenic.

In biochemical extraction experiments, the majority of the muscle-specific proteins behave like components of the detergent and salt-insoluble extracellular matrix (Rojkind et al., 1980; Carter and Hakomori, 1981; Wicha et al., 1982; Chiquet and Acklin, 1986). Laz10-1-stained bands do not comigrate with any of the known detergent-insoluble intracellular proteins of the leech muscle cytoskeleton (Lehman and Szent-Györgyi, 1975; Winkelman, 1976). The minor salt-soluble fraction could consist of precursor molecules, which have not yet been incorporated into this matrix, or of breakdown products. In contrast, the cell-type-specific 130-kDa proteins of neurons and glial cells behave like loosely attached peripheral membrane proteins (Bajt et al., 1990; Cole et al., 1990).

Our findings on the early development of individual myogenic cells within the hirudinid germinal plate are summarized in Figure 8 . The first indicator of segmentation is a chain of 32 segmental myogenic cells at the embryonic midline that prefigure the spacing of the bilateral somites. These midline myogenic cells develop into the CNS muscles. Their processes define the cell-free corridor at the midline that will develop into the connectives and the ganglionic neuropil regions. The earliest bilateral myogenic cells, which differentiate from bilateral mesodermal cells in a stereotypical sequence near the midline, develop into the blood sinus muscle precursors. The cell bodies of CNS muscle and lateral, dorsal, and ventral blood sinus muscle precursors, like cornerstones, demarcate the anterior and posterior borders of the developing segmental hemiganglionic primordia (Fig. 8 inset, N). The processes of CNS muscle precursors define the medial border of each hemiganglionic primordium, while the processes of the three groups of blood sinus muscle precursors define its lateral, dorsal, and ventral borders, thereby separating it from peripheral tissue. The midline myogenic cells and differentiating bilateral myogenic cells are stained strongly and continuously with Laz10-1, as are adult muscle cells.

Furthermore, we demonstrated that the Laz10-1 epitope is also expressed by undifferentiated mesoblasts. Mesoblasts, which occur stereotypically at the dorsolateral aspects of the germinal plate, previously were observed predominantly to give rise to adult muscle cells (Weisblat and Shankland, 1985). The intensity 
of this mesodermal Laz10-1 stain fluctuates (Fig. 8, stippling); it is highest in the nascent mesoderm and in newly formed somites and low during proliferative phases. Within the mesoderm, the Laz10-1 epitope is distributed in broad, diffuse layers that include the margins of mesoblast cell bodies and extracellular spaces surrounding them. This cellular distribution provides further evidence that, in adult and embryonic leeches, the Laz10-1 epitopc is cxpressed on components of the extracellular matrix produced by muscle cells or mesodermal/myogenic cells, respectively. Mesoblasts are surrounded by a diffuse layer of Laz10-1 epitopes whose concentration fluctuates. In contrast, differentiating muscle precursors and adult muscles continuously express high levels of Laz10-1 epitopes intracellularly and, presumably, in the immediate vicinity of their cell surfaces. These differences in the distribution of the Laz10-1 epitopes may indicate physiological differences that can be tested in antibody perturbation experiments.

\section{Correlation between the differentiation pattern of myogenic cells and the segmental pattern of the CNS}

Using the Laz10-1 antigen as a marker for myogenic cells indicated that the $m$ bandlet-derived mesoderm gives rise to the muscle cells of the CNS and the peripheral body wall. This result is in agreement with carlier data from cell lineage studies (Zackson, 1982; Weisblat and Shankland, 1985). Novel findings reported here are (1) the temporal and spatial pattern in which individual myogenic cells appear and differentiate, and (2) their association with neuroblasts developing into segmental hemiganglionic primordia.

Morphologically differentiated myogenic cells are detected at the midline of the germinal plate before any of the bilateral mesodermal cells within the $\mathrm{m}$ bandlet have ceased to divide and have begun their differentiation. The lineage of these midline myogenic cells has not yet been determined. Their most likely source is either the $\mathbf{M}$ teloblasts or the micromeres, which give rise to some of the transient larval tissues (Fernandez and Stent, 1982; Sawyer, 1986). The midline myogenic cells form a chain that extends a short distance past the $M$ teloblasts onto the posterior larval envelope. While producing blast cells, the teloblasts are displaced posteriorly along the midline myogenic cells by the growing bandlets. The midline myogenic cells may play a role in guiding this movement of the teloblasts.

The midline myogenic cells are the third cell type that has now been identified at the midline of the hirudinid leech germinal plate. The two other cell types, which were detected through mAbs, are the midline cells expressing the neuronal Lan3-2 epitope (McGlade-McCulloh et al., 1990) and primordial glial cells expressing the glia-specific Laz6-297 epitope (Cole et al., 1989). These three types of midline cells differ in the position of their cell bodies. The cell bodies of the Laz10-1-stained midline myogenic cells are segmentally reiterated; in contrast, the cell bodies of the Lan3-2-stained midline cells are more abundant in the anterior germinal plate (McGlade-McCulloh et al., 1990). Cell bodies of the Laz6-297-stained primordial glial cells were only infrequently observed within the germinal plate (Cole et al., 1989; R. N. Cole and B. Zipser, unpublished observations). Because of their temporal, spatial, and molecular characteristics, all three types of midline cells are candidates for providing instructional cues for the genesis of the hirudinid nervous system.

The 32 midline myogenic cells are of particular interest, because their spacing constitutes the first indicator of the future segmentation of the embryo, preceding the rearrangement of the bilateral mesoderm into somites. Hirudinid left and right somites arise simultaneously at exactly symmetrical positions (Fernandez and Stent, 1982). This contrasts with mesoderm development in glossiphoniid leeches, in which segmentation occurs independently in the spatially separated left and right germinal bands, with alignment taking place later (Weisblat et al., 1978, 1980, 1984; Weisblat and Stent, 1982; Zackson, 1982; Weisblat and Shankland, 1985). The presence of the $32 \mathrm{seg}-$ mentally iterated midline myogenic cells in the hirudinid germinal plate offers a possible mechanism by which positional cues are provided for the precise spacing of the somites. It remains to be seen whether the medial aspects of the left and right germinal bands in glossiphoniids are flanked by cell types analogous to the midline myogenic cells, primordial glial cclls, or Lan3-2-reactive midline cells.

The midline myogenic cells appear to develop into the first precursors of adult muscles, which are the CNS muscle precursors, as determined by following their development along the posterior-to-anterior developmental gradient of the same embryos. This finding is in agreement with cell lineage studies on the origin of the medial of the two pairs of CNS muscles in glossiphoniid leeches. While ultimately derived from the $\mathrm{M}$ teloblast (Weisblat et al., 1984; Kramer and Weisblat, 1985; Weisblat and Shankland, 1985), the medial CNS muscle pair was already localized at the midline during gangliogenesis (Kuwada and Kramer, 1983).

The lateral, dorsal, and ventral blood sinus muscle precursors are the second type of adult muscles to develop. They differentiate at segmentally iterated, stereotypical positions that coincide with the borders of the territory within which neuronal precursors proliferate and coalesce into hemiganglionic primordia. This observation leads to our hypothesis that the precursors of the CNS-associated muscles provide boundary cues for the neuroblasts.

In glossiphoniid leeches, neuroblast development was found to be perturbed after experimental ablations of the ipsilateral mesodermal bandlet. Neurogenic blast cells seem to have an intrinsic ability to differentiate after undergoing a sequence of stereotyped cell divisions (Bissen and Weisblat, 1987; Stuart et al., 1989). However, the mesoderm seems to be necessary for neuroblast orientation during the developmental period prior to ganglion formation, because the spatial pattern of neuroblast divisions was disturbed when mesoderm was absent (Zackson, 1984). Due to this dislocation of neuroblasts, orderly ganglionic primordia did not form (Torrence et al., 1989). We postulate that the CNS and blood sinus muscle precursors, whose development we have followed in the hirudinid leech, are the mesodermal cell types responsible for orchestrating the coalescence of neuroblasts into segmental hemiganglionic primordia.

Peripheral muscle cells have been postulated to provide cues for centripetal migration of neuroblasts generated in the periphery by o, p, q, and $m$ bandlets (Torrence and Stuart, 1986). Furthermore, muscle and identifiable mesodermal cells have also been implicated in axonal pathfinding (Kramer and $\mathrm{Ku}-$ wada, 1983; Kuwada and Kramer, 1983; Kuwada, 1985; Jellies and Kristan, 1988a).

\section{The level of expression of muscle-specific protein changes during development}

The intensity with which Laz10-1 stains mesodermal/myogenic cells at different developmental stages varies greatly. A clear 
correlation exists between the amount of the muscle-specific protein expressed and the morphogenetic movements of bilateral mesodermal cells. The muscle-specific protein is expressed at a clearly detectable level by nascent mesoblasts, as they arrange themselves into the $m$ bandlet. As the mesoblasts begin to proliferate, their level of muscle-specific protein is attenuated. As mesodermal cells rearrange themselves into somites, they experience a renewed rise in muscle-specific protein. After somites have formed, the expression of muscle-specific protein again decreases, as long as the mesoderm remains undifferentiated. Individual muscle precursors starting their myogenic differentiation express sharply elevated levels of muscle-specific protein, in contrast to the surrounding undifferentiated mesoderm. The muscle-specific protein now persists as the myogenic cclls first develop into muscle precursors and then into adult muscles. By producing changing levels of muscle-specific protein, mesodermal and myogenic cells of the leech may regulate the properties of the adhesive substrate surrounding them during their morphogenetic navigation.

In vertebrates, extracellular matrix proteins are postulated to provide a scaffold for the morphogenesis of muscle (Chiquet and Fambrough, 1984; Jaffredo et al., 1988; Gatchalian et al., 1989; Goodman et al., 1989; Hunter et al., 1989) and nervous tissue (Bronner-Fraser, 1985, 1986; Grumet et al., 1985; Thiery et al., 1985; Steindler et al., 1989). It remains to be explored with antibody perturbation studies whether the Laz 10-1 epitope influences different morphogenetic processes-for example, whether it plays a role in mesodermal rearrangements and the early morphogenesis of the CNS reported here, or in the later guidance of neuronal migration and axonal growth by muscle cells.

\section{References}

Bajt ML, Cole RN, Zipser B (1990) The specificity of the $130-\mathrm{kDa}$ leech sensory afferent proteins is encoded by their carbohydrate epitopes. J Neurochem 55:2117-2125.

Bissen ST, Weisblat DA (1987) Early differences between alternate n blast cells in leech embryo. J Neurobiol 18:251-269.

Blair SS (1982) Interactions between mesoderm and ectoderm in segment formation in the embryo of a glossiphoniid leech. Dev Biol 89: 389-396.

Braun J, Stent GS (1989) Axon outgrowth along segmental nerves in the leech. I. Identification of candidate guidance cells. Dev Biol 132: $471-485$.

Bronner-Fraser M (1985) Alterations in neural crest migration by a monoclonal antibody that affects cell adhesion. J Cell Biol 101:610617.

Bronner-Fraser M (1986) An antibody to a receptor for fibronectin and laminin perturbs cranial neural crest development in vivo. Dev Biol 117:528-536.

Carter WG, Hakomori S (1981) A new cell surface, detergent-insoluble glycoprotein matrix of human and hamster fibroblasts. J Biol Chem 256:6953-6960.

Chiquet M, Acklin SE (1986) Attachment to ConA or extracellular matrix initiates rapid sprouting by cultured leech neurons. Proc Natl Acad Sci USA 83:6188-6192.

Chiquet M, Fambrough DM (1984) Chick myotendinous antigen. I. A monoclonal antibody as a marker for tendon and muscle morphogenesis. J Cell Biol 98:1926-1936.

Chiquet-Ehrismann R, Mackie EJ, Pearson CA, Sakakura T (1986) Tenascin: an extracellular matrix protein involved in tissue interactions during fetal development and oncogenesis. Cell 47:131-139.

Coggeshall RE, Fawcett DW (1964) The fine structure of the central nervous system of the leech, Hirudo medicinalis. J Neurophysiol 27: 229-289.

Cole RN, Zipser B (1990) Cell-type specific peripheral and integral membrane proteins and their complementary mannose-binding protein in the leech CNS. Soc Neurosci Abstr 16:1010.
Cole RN, Morell RJ, Zipser B (1989) Glial processes, identified through their glial-specific $130 \mathrm{kD}$ surface glycoprotein, are juxtaposed to sites of neurogenesis in the leech germinal plate. Glia 2:446-457.

England MA (1986) Aspects of somite formation in the early chick embryo. In: NATO ASI Series A: life sciences, Vol 118, Somites in developing embryos (Bellairs R, Ede D, Lash J, eds), pp 47-60. New York: Plenum.

Fernandez J, Stent GS (1982) Embryonic development of the hirudinid leech Hirudo medicinalis: structure, development and segmentation of the germinal plate. J Embryol Exp Morphol 72:71-96.

Flaster MS, Zipser B (1987) The macroglial cells of the leech are molecularly heterogeneous. J Neurosci Res 17:176-183.

Flaster MS, Schley C, Zipser B (1983) Generating monoclonal antibodies against excised gel bands to correlate immunocytochemical and biochemical data. Brain Res 277:196-199.

Gatchalian CL, Schachner M, Sanes JR (1989) Fibroblasts that proliferate near denervated synaptic sites in skeletal muscle synthesize the adhesive molecules tenascin $(\mathrm{J} 1), \mathrm{N}-\mathrm{CAM}$, fibronectin, and a heparan sulfate proteoglycan. J Cell Biol 108:1873-1890.

Goodman SL, Risse G, Mark KVD (1989) The E8 subfragment of laminin promotes locomotion of myoblasts over extraccllular matrix. J Cell Biol 109:799-809.

Grumet M, Hoffman S, Crossin KL, Edelman GM (1985) Cytotactin, an extracellular matrix protein of neural and non-neural tissues that mediates glia-neuron interaction. Proc Natl Acad Sci USA 82:80758079.

Hatta K, Takeichi M (1986) Expression of N-cadherin adhesion molecules associated with early morphogenetic events in chick development. Nature 320:447-449.

Ho RK, Goodman CS (1982) Peripheral pathways are pioneered by an array of central and peripheral neurones in grasshopper embryos. Nature 297:404-406.

Ho RK, Ball EE, Goodman CS (1983) Muscle pioneers: large mesodermal cells that erect a scaffold for developing muscles and motoneurones in grasshopper embryos. Nature 301:66-69.

Hogg N, Flaster M, Zipser B (1983) Cross-reactivities of monoclonal antibodies between select leech neuronal and epithelial tissues. J Neurosci Res 9:445-457.

Hunter DD, Shah V, Merlie JP, Sanes JR (1989) A laminin-like adhesive protein concentrated in the synaptic cleft of the neuromuscular junction. Nature 338:229-234.

Jaffredo T, Horwitz AF, Buck CA, Rong PM, Dieterlen-Lievre F (1988) Myoblast migration specifically inhibited in the chick embryo by grafted CSAT hybridoma cells secreting an anti-integrin antibody. Development 103:431-446.

Jellies J, Kristan WB Jr (1988a) An identified cell is required for the formation of a major nerve during embryogenesis in the leech. $J$ Neurobiol 19:153-165.

Jellies J, Kristan WB Jr (1988b) Embryonic assembly of a complex muscle is directed by a single identified cell in the medicinal leech. $\mathrm{J}$ Neurosci 8:3317-3326.

Keynes RJ, Stern CD (1987) Mechanisms of vertebrate segmentation. Development 103:413-429.

Kramer AP, Kuwada JY (1983) Formation of the receptive fields of leech mechanosensory neurons during embryonic development. J Neurosci 3:2474-2486.

Kramer AP, Weisblat DA (1985) Developmental neural kinship groups in the leech. J Neurosci 5:388-407.

Kuwada JY (1985) Pioneering and pathfinding by an identified neuron in the developing leech. J Embryol Exp Morphol 86:155-167.

Kuwada JY, Kramer AP (1983) Embryonic development of the leech nervous system: primary axon outgrowth of identified neurons. J Neurosci 3:2098-2111.

Laemmli UK (1970) Cleavage of structural proteins during the assembly of the head of bacteriophage T4. Nature 227:680-685.

Lanzavecchia G (1977) Morphological modulations in helical muscles (Aschelminthes and Annelida). Int Rev Cytol 51:133-186.

Lash JW, Yamada KM (1986) In: NATO ASI Series A: life sciences, Vol 118, Somites in developing embryos (Bellairs R, Ede D, Lash J, eds), pp 201-208. New York: Plenum.

Lehman W, Szent-Györgyi AG (1975) Regulation of muscular contraction. Distribution of actin control and myosin control in the animal kingdom. J Gen Physiol 66:1-30.

McGlade-McCulloh E, Muller KJ, Zipser B (1990) Expression of surface glycoproteins early in leech natural development. J Comp Neurol 299:123-131. 
McKay R, Johansen J, Hockfield S (1984) Monoclonal antibody identifies a 63,000 dalton antigen found in all central neuronal cell bodies but in only a subset of axons in the leech. J Comp Neurol 226:448455.

Peinado A, Macagno ER, Zipser B (1987) A group of related surface glycoproteins distinguish sets and subsets of sensory afferents in the leech nervous system. Brain Res 410:335-339.

Pucci I, Afzelius BA (1967) An electron microscope study of sarcotubules and related structures in the leech muscle. J Ultrastruct Res $7: 210-224$

Rojkind M, Gatmaitan Z, Mackensen S, Giambrone MA, Ponce P, Reid LM (1980) Connective tissue biomatrix: its isolation and utilization for long-term cultures of normal rat hepatocytes. J Cell Biol 87:255263.

Rosenbluth J (1972) Obliquely striated muscle. In: Structure and function of muscle, Vol I, Structure, Pt 1 (Bourne GH, ed), pp 389-420. London: Academic.

Rutishauser U (1984) Developmental biology of a neural cell adhesion molecule. Nature 310:549-554.

Sawyer RT (1986) Leech biology and behaviour, Vol I, Anatomy, physiology, and behaviour. Oxford: Clarendon.

Steindler DA, Cooper NGF, Faissner A, Schachner M (1989) Boundaries defined by adhesion molecules during development of the cerebral cortex: the $\mathrm{J} 1 /$ tenascin glycoprotein in the mouse somatosensory cortical barrel field. Dev Biol 131:243-260.

Stern CD, Keynes RJ (1987) Interactions between somite cells: the formation and maintenance of segment boundaries in the chick embryo. Development 99:261-272.

Stuart DK, Torrence SA, Law MI (1989) Leech neurogenesis I. Positional commitment of neural precursor cells. Dev Biol 136:17-39.

Thiery JP, Duband JL, Tucker GC (1985) Cell migration in the vertebrate embryo: role of cell adhesion and tissue environment in pattern formation. Annu Rev Cell Biol 1:91-113.

Torrence SA, Stuart DK (1986) Gangliogenesis in leech embryos: migration of neural precursor cells. J Neurosci 6:2736-2746.
Torrence SA, Law MI, Stuart DK (1989) Leech neurogenesis II. Mesodermal control of neuronal patterns. Dev Biol 136:40-60.

Tosney KW, Watanabe M, Landmesser L, Rutishauser U (1986) The distribution of NCAM in the chick hindlimb during axon outgrowth and synaptogenesis. Dev Biol 114:437-452.

Towbin H, Staehelin T, Gordon J (1979) Electrophoretic transfer of proteins from polyacrylamide gels to nitrocellulose sheets: procedure and some applications. Proc Natl Acad Sci USA 76:4350-4354.

Tulsi RS, Coggeshall RE (1971) Neuromuscular junctions on the muscle cells in the central nervous system of the leech, Hirudo medicinalis. J Comp Neurol 141:1-16.

Weisblat DA, Shankland M (1985) Cell lineage and segmentation in the leech. Philos Trans R Soc Lond [Biol] 312:39-56.

Weisblat DA, Stent GS (1982) Cell lineage analysis by intracellular injection of tracer substances. Curr Top Dev Biol 17:1-31.

Weisblat DA, Sawyer RT, Stent GS (1978) Cell lineage analysis by intracellular injection of a tracer enzyme. Science 202:1295-1298.

Weisblat DA, Zackson SL, Blair SS, Young JD (1980) Cell lineage analysis by intracellular injection of fluorescent tracers. Science 209: 1538-1541.

Weisblat DA, Kim SY, Stent GS (1984) Embryonic origins of cells in the leech Helobdella triserialis. Dev Biol 104:65-85.

Wicha MS, Lowrie G, Kohn E, Bagavandoss P, Mahn T (1982) Extracellular matrix promotes mammary epithelial growth and differentiation in vitro. Proc Natl Acad Sci USA 79:3213-3217.

Winkelman L (1976) Comparative studies of paramyosins. Comp Biochem Physiol 55B:391-397.

Zackson SL (1982) Cell clones and segmentation in leech development. Cell 31:761-770.

Zackson SL (1984) Cell lineage, cell-cell interaction, and segment formation in the ectoderm of a glossiphoniid leech embryo. Dev Biol 104:143-160.

Zipser B, Morell R, Bajt ML (1989) Defasciculation as a neuronal pathfinding strategy: involvement of a specific glycoprotein. Neuron $3: 621-630$. 